\title{
ELECTROCHEMICAL TREATMENT OF LEACHATE BY MONOPOLAR CONFIGURATION USING IRON ELECTRODE
}

\author{
Nethravathi V S ${ }^{1}$, Krishna B $\mathbf{M}^{2}$ \\ ${ }^{I}$ M. Tech, Department of Environmental Engineering, Sri Jayachamarajendra College of Engineering, Mysuru, \\ Karnataka, India \\ ${ }^{2}$ Associate professor, Department of Environmental Engineering, Sri Jayachamarajendra College of Engineering, \\ Mysuru, Karnataka, India
}

\begin{abstract}
In this study the treatment of sanitary landfill leachate is carried out by Batch electrocoagulation process using iron and aluminium electrodes in monopolar configuration. The effect of $\mathrm{pH}$, Electrolysis time and cell voltage on COD removal was studied. The maximum removal efficiency of $77 \%$ was achieved using iron electrode at optimum voltage of $6 \mathrm{~V}$ at $\mathrm{pH} 8$ for electro duration of 70 minutes. The energy consumption observed was $0.051 \mathrm{kwh} / \mathrm{L}$ of wastewater. Pseudo-first-order and pseudo second order models have been used to fit the experimental data for COD removal using iron electrode. Therefore the EC can be used as for promising treatmet technology for the removal of COD from sanitary landfill leachate.
\end{abstract}

Keywords: Leachate, Electrocoagulation, chemical oxygen demand. Iron electrode.

\section{INTRODUCTION}

Now days due to rapid growth of population, urbanization and industrialization, solid waste management become a serious issue. In the solid waste management the most common technique used for final disposal of the solid waste over the world is sanitary landfill (Gurses et al., 2002). Landfill is the one of the most prevalent methods used by many countries and leachate is commonly generated from precipitation, surface run-off, and infiltration or intrusion of groundwater percolating through the landfill (Akshatha et al., 2016). The leachate therefore is defined as hazardous and heavily polluted wastewater and is dark in colour, bad odour, high conductivity and ammonium as well as increased concentration of heavy metals. The best method of controlling the environmental pollution and health risks by leachate is treating the leachate to remove the hazardous substances before it discharges the water system Junling et al., 2014).

It is necessary to enhance the leachate treatment, in order to fully reduce negative impact on the environment. Complete or partial treatment can be done on-site where the leachate is produced or at an off-site facility. There are different methods to treat the landfill leachate, such as aerobic and anaerobic biological treatment, flotation, air stripping, coagulation-flocculation, chemical precipitation, activated carbon adsorption, membrane filtration, Ion exchange treatment (Rosie et al., 2012). For the characteristics of leachate change with advancing years of the landfill, these methods have some shortages such as decreasing treatment efficiencies and increasing cost. Therefore, some effective and economical treatment methods need to be developed to solve these problems.
In this context electrochemical methods offer a good opportunity to prevent and remedy for environmental impacts due to the discharge of industrial and sewage effluents. EC involves the generation of coagulant insitu by dissolution of metal from the anode with simultaneous formation of hydroxyl ions and hydrogen gas at the cathode.

\section{MATERIALS AND METHODS}

\subsection{Sanitary Landfill Leachate}

The leachate was collected from landfill site at Mysuru, India and characterized as per standard methods. The physico-chemical characteristics of the raw leachate are given in Table 1. Treatability studies were carried out in 2.3L batch reactor with working volume of $2 \mathrm{~L}$

\subsection{Electrolysis Experiments}

Batch electrocoagulation experiments were performed using raw leachate at its existing $\mathrm{pH}$ and at room temperature $\left(28^{\circ} \mathrm{C}\right)$ using $2 \mathrm{~L}$ working volume in a reactor with a capacity of 2.3 L. Two number of Iron electrode having a cross sectional area $7 \mathrm{~cm} \times 5 \mathrm{~cm}$ was used in each experimental run with inter electrode distance of $2 \mathrm{~cm}$ arranged in monopolar mode. The EC reactor was provided with magnetic stirrer stirring at $300 \mathrm{rpm}$ to maintain homogenity of leachate within the reactor.The aliquoit of samples were collected at different time intervals upto 90 mins, filtered and analyzed for COD, $\mathrm{pH}$ and BOD. After each experiment, the electrode were cleaned dried and weighed. \% COD removal was calculated using the equation 1

$$
\% \text { COD Removal }=\frac{C_{0} \times C_{f}}{C_{0}} \times 100
$$


Where,

$\mathrm{C}_{0}=$ Initial COD in $\mathrm{mg} / \mathrm{L}$

$\mathrm{C}_{\mathrm{f}}=$ Final $\mathrm{COD}$ in $\mathrm{mg} / \mathrm{L}$

Table 1: Physico-chemical charecteristics of sanitary landfill leachate

\begin{tabular}{|l|l|}
\hline Parameters & Values \\
\hline $\mathrm{Ph}$ & 8.17 \\
\hline Conductivity $\mu \mathrm{S} / \mathrm{cm}$ & 30 \\
\hline Turbidity NTU & $160-250$ \\
\hline Total Dissolve solids (mg/L) & 17720 \\
\hline Chemical oxygen demand (mg/L) & 8300 \\
\hline $\begin{array}{l}\text { Biochemical Oxygen Demand } \\
(\mathrm{mg} / \mathrm{L})\end{array}$ & 3400 \\
\hline Suspended Solids (mg/L) & 294 \\
\hline Phosphate (mg/L) & 494 \\
\hline Ammonia Nitrogen (mg/L) & 603 \\
\hline
\end{tabular}

\section{RESULTS AND DISCUSSION}

\subsection{Electrocoagualtion using Iron Electrodes}

The effect of electrolysis time (ET) and cell voltage for COD removal was studied using iron electrodes arranged in monopolar configuration

The effect of $\mathrm{pH}$ with respect to ET at different voltage is shown in Figure 1. It can be observed from figure. 1 that, increase in cell voltage and ET, the $\mathrm{pH}$ of the system increases. Initial $\mathrm{pH}$ of raw leachate was in the range of 8.28.4 and after electrolysis it reached to 9.6 at an voltage of $10 \mathrm{~V}$ after $90 \mathrm{~min} \mathrm{ET}$. The increase in $\mathrm{pH}$ with increase in voltage and with respect to ET may be attributed to the release of hydroxide ions during the electrocoagulation.

\subsubsection{Effect of ET and Cell Voltage on COD Removal}

Determining optimum range of applied voltage will give the benefit of reducing operating cost. In this study, the cell voltages applied were $4 \mathrm{~V}, 6 \mathrm{~V}, 8 \mathrm{~V}$ and $10 \mathrm{~V}$. A plot of $\%$ COD removal versus ET for varied applied voltages using iron electrode has been shown in Figure 2. From Figure, it can be observed that $65 \%$ COD removal occured after 90 min ET at $6 \mathrm{~V}$. The fluctuation in \% COD removal may be due to the instantaneous release and consumption of the metal hydroxides during the EC process.

Figure 2 shows that maximum COD removal effeciency of $76 \%$ was observed at current density $0.14 \mathrm{~A} / \mathrm{cm}^{2}$ at $70 \mathrm{~min}$ ET. The energy consumption of the process at optimum voltage $0.051 \mathrm{kwh} / \mathrm{L}$. Similarly, $81 \%, 77 \%, 31 \%$ and $54 \%$ of COD removal were observed at $4 \mathrm{~V}, 6 \mathrm{~V}, 8 \mathrm{~V}, 10 \mathrm{~V}$, with the corresponding current density of $0.14,0.32,0.19$ and 0.3 $\mathrm{A} / \mathrm{cm}^{2}$ respectively.

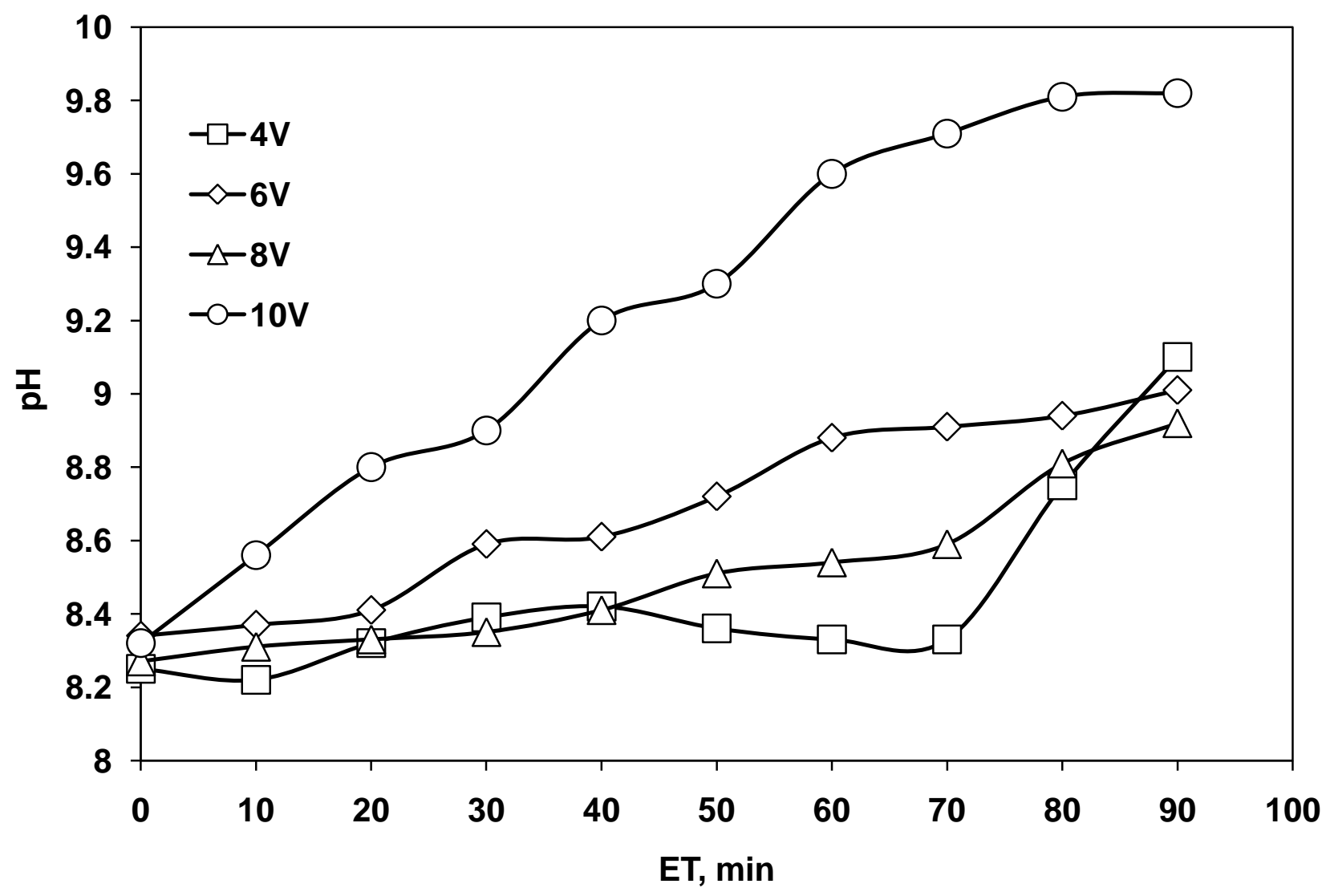

Fig 1: Variation of $\mathrm{Ph}$ in the ET for different voltage using Iron electrode 


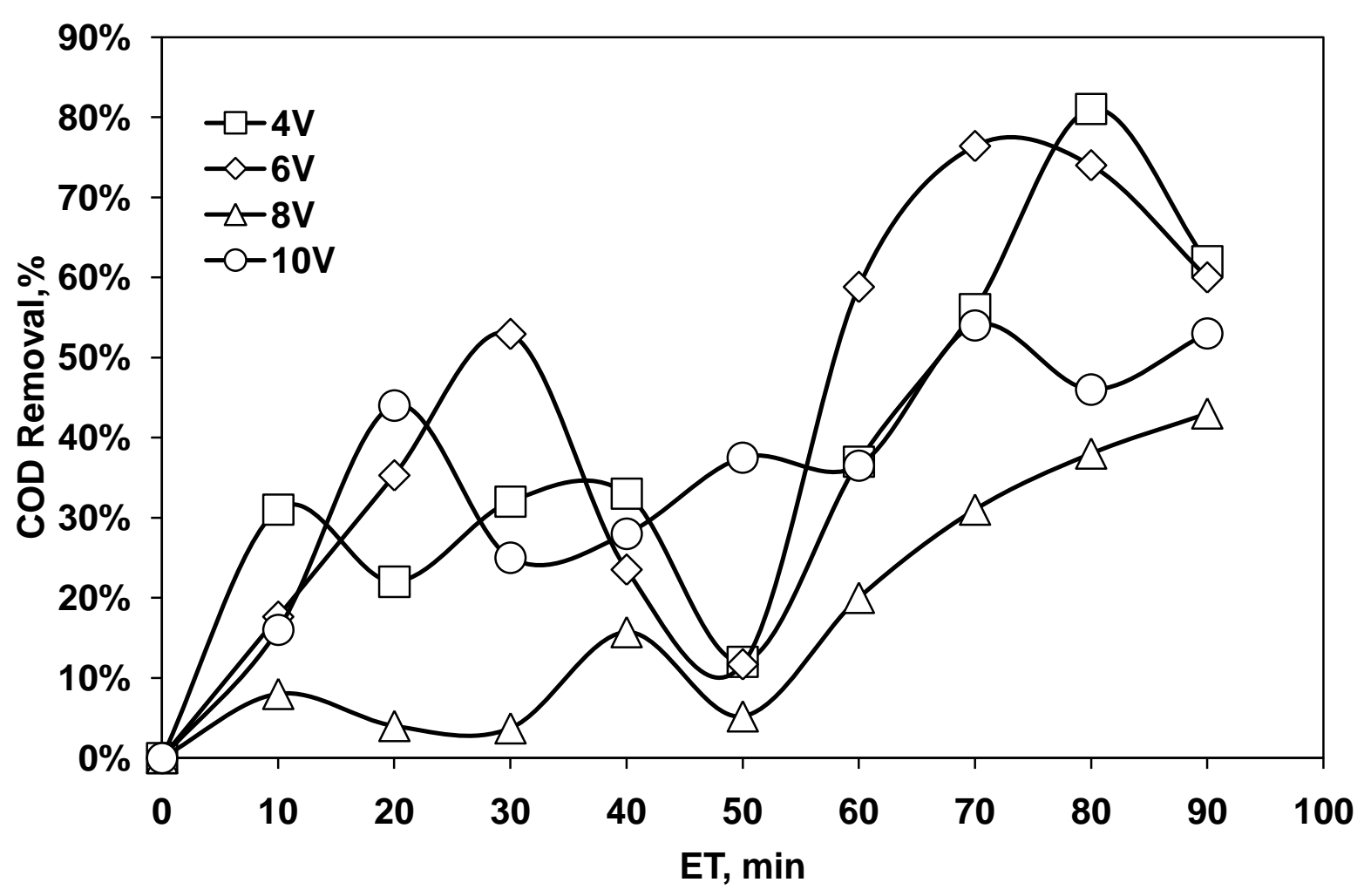

Fig 2: Effect of cell voltage on \% COD removal with ET using Iron electrode

\subsection{Sludge Analysis}

Sludge produced due to ionic bridging between the finely divided particles to make flocs followed by their grouping into large aggregates to be settled under gravity. Here $7.28 \mathrm{~g}$ of dry sludge produced after electrolysis for iron electrode at 6V. Analysed for heavy metals like Iron, aluminium, chromium, nickel, copper lead, tin etc.,

\subsection{Kinetic Studies}

Kinetic study helps us to know the order and rate of reaction. In this study, the experimental data was fitted with two most widely used kinetic models i.e. pseudo-first-order and pseudo-second-order model as shown in Figure 3 and Figure 4 respectively. It can be observed that, co-efficient of determination $\left(\mathrm{R}^{2}\right)$ was higher for pseudo-second-order model compared with pseudo-first-order model, indicating that COD removal follows pseudo-second-order kinetic model and Equation 2 and 3 are the linear equations for the same.

$$
\begin{aligned}
& \ln \left(q_{e}-q_{t}\right)=\ln q_{e}-k_{1} t \\
& \frac{1}{q_{t}}=\frac{1}{k_{1} q_{e} 2}+\frac{1}{q_{e}}
\end{aligned}
$$




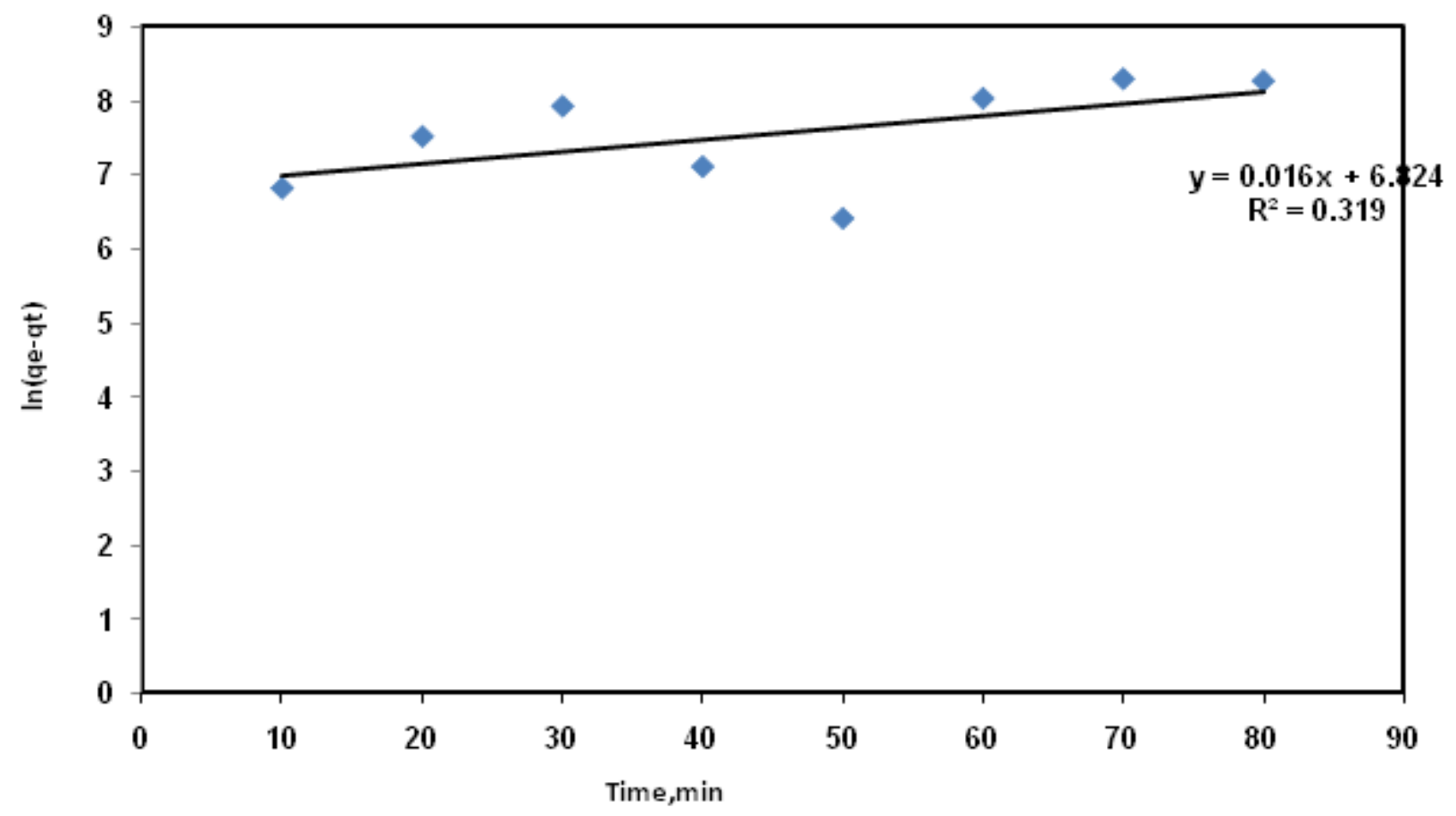

Fig 3: Pseudo first order kinetics for results obtained by using iron as electrode

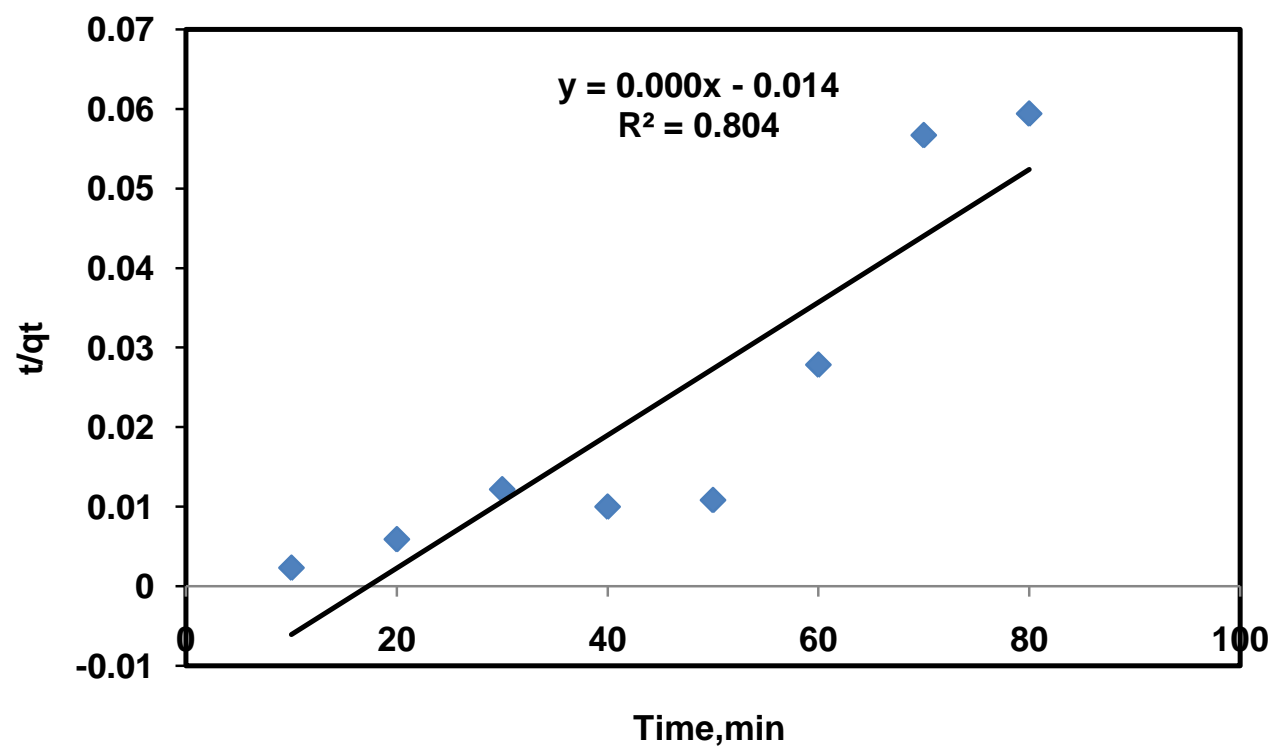

Fig 4: Pseudo-second-order kinetic model for iron electrode

\section{CONCLUSION}

In this study, batch electrocoagulation process using iron and aluminum electrodes arranged in mono polar configuration was used for COD removal from sanitary landfill leachate.The maximum COD removal of $77 \%$ was achieved at $6 \mathrm{~V}$ with the corresponding current density of $0.14 \mathrm{~A} / \mathrm{cm}^{2}$ by using iron electrode and minimum energy consumption observed was $0.051 \mathrm{kwh} / \mathrm{L}$. Therefore, Iron electrode can be considered as an efficient electrode. Kinetic study reveals that the removal using iron electrod follows pseudo-second-order model. The EC method does not use any chemical reagents and makes the process of leachate treatment high effeciency, easy for regulation and automation. Therefore EC process can be considered for the treatment of sanitary landfill leachate. To meet the standards further polishing technologies can be suggested. 


\section{REFFERENCES}

[1] A.Gurses, M. Yalcin, and C. Dogan, (2002)," Waste Management", Vol. 22.

[2] Akshatha, Roopeshree G.B, Lokesh K.S, “ Comparitive study of electrode material for treatment of textile industry wastewater" International Journal of Environmental Science, Vol. 4, PP 519-531.

[3] Junling Gao, Violet Oloibiri, Michael Chys, Wim Audenaert, Bjorge Decostere, Yanling He, Herman Van Langenhove, Kristof Demeestere, Stijn W. H. Van Hulle, (2014). "The present status of landfill leachate treatment and its development trend from a technological point of view" Rev Environ Sci Biotechnicol.

[4] Rosie Jotin, Shaharin Ibrahim and Normala Halimoon, (2012) Electrocoagulation for removal of chemical oxygen demand in sanitary landfill leachate", International Journal of Environmental Sciences, Vol 3, PP 921-930.

[5] P.Canizares, M.Carmona, J.Lobato, F.Martınez, M.A.Rodrigo, (2005), "Electrodissolution of Aluminum Electrodes in Electrocoagulation Processes", Industrial and Engineering Chemistry Research, Vol. 44, PP 4178-4185. 